\title{
Pengembangan Teknik Peer Review Berbantuan Artikel Media Daring dalam Pembelajaran Menulis Bahasa Perancis
}

\author{
Yadi Mulyadi, Tri Indri Hardini, dan Iis Sopiawati \\ Universitas Pendidikan Indonesia
}

Corresponding authors.yadimulyadi@upi.edu; tihardini@upi.edu; sopiawati503@upi.edu

How to cite this article (in APA Style). Mulyadi, Y., Hardini, T.I., \& Sopiawati, I. (2021). Pengembangan teknik peer review berbantuan artikel media daring dalam pembelajaran menulis Bahasa Perancis. Jurnal Pendidikan Bahasa dan Sastra, 21(1), 111-122. https://doi.org/10.17509/bs_jpbsp.v21i1.36664

History of article. Received: November 2020; Revised: February 2021; Published: April 2021

\begin{abstract}
Abstrak: Keterampilan menulis bukanlah merupakan keterampilan yang diperoleh pembelajar secara alamiah melainkan perlu dipelajari dan dibudayakan pelatihannya baik secara formal maupun di lingkungan belajar lainnya. Tujuan penelitian ini adalah untuk : (1) mengkaji penerapan teknik Peer review berbantuan artikel media daring untuk meningkatkan keterampilan menulis mahasiswa dalam pembelajaran Production Ecrite 2; dan (2) memperoleh data keterampilan menulis mahasiswa dalam menulis teks berita bahasa Perancis untuk level A2 DELF. Dalam pelaksanaannya, metode penelitian yang digunakan yaitu metode praeksperimental dengan desain The one groupe pre-test post-test design melalui tiga tahap, yaitu: 1) tahap prates; 2) tahap perlakuan; dan 3) tahap pascates. Dari data-data penelitian yang telah dianalisis, diperoleh temuan bahwa rata-rata skor tes awal sebesar $=67,46$, ini menunjukan kemampuan awal mahasiswa tentang materi yang diujikan masih sangat rendah karena umumnya mahasiswa belum mempelajarinya. Setelah diberikan perlakuan berupa pembelajaran dengan teknik Peer review, diperoleh hasil rata-rata skor tes akhir sebesar 79,55. Terjadinya peningkatan hasil tes ini dikarenakan mahasiswa telah membuat teks berita berdasarkan pengetahuan yang telah dipelajarinya dari perlakuan pembelajaran yang telah diberikan. Merujuk pada hasil penelitian, diperoleh informasi bahwa teknik pembelajaran yang diteliti telah terbukti efektif dan mampu meningkatkan keterampilan mahasiswa dalam menulis teks berita bahasa Perancis untuk tingkat A2.
\end{abstract}

Kata kunci: Peer review; keterampilan menulis; FLE; kompetensi A2 DELF CECRL

\section{Development of Peer Review Technique Assisted by Online Media Articles in French Writing Class}

\begin{abstract}
Writing skills are not skills that learners naturally acquire, but need to be learned and cultivated for training both formally and in other learning environments. The purpose of this study was to: (1) examine the application of the Peer review technique assisted by online media articles to improve students' writing skills in Production Ecrite 2 learning; and (2) obtain data on students' writing skills in writing French news texts for A2 DELF level. In practice, the research method used is a pre-experimental method with the design of the one groupe pre-test post-test design through three stages, namely: 1) the pre-test stage; 2) the treatment stage; and 3) the post-test stage. From the research data that has been analyzed, it is found that the average initial test score of the experimental class $=67.46$, this shows that the students' initial ability about the material being tested is still very low because generally students have not studied it. After being given treatment in the form of learning with the Peer review technique, a final test was held with an average score of 79.55. There is an increase in the results of this test, because students make informative texts based on the knowledge they have learned from the learning treatment that has been given. Referring to the results of the study, it is found that the learning techniques studied have been proven effective and are able to improve the French language informative text writing skills for level A2.
\end{abstract}

Keywords: Peer review; writing skills; FLE; competency A2 DELF CECRL 


\section{Pendahuluan}

Keterampilan berbahasa asing (dalam hal ini bahasa Perancis) tidak dapat dimiliki oleh seorang pembelajar dalam waktu relatif singkat tetapi diperlukan waktu yang cukup sesuai dengan tujuan pembelajaran yang hendak dicapai (Graham, 2004; Rahmat, Mulyadi \& Sopiawati, 2007; Williams, Burden, Poulet, \& Maun, 2004). Tujuan pembelajaran dimaksud yaitu tujuan pemerolehan keterampilan berbahasa Perancis yang mengarah pada kompetensi berbahasa dengan merujuk pada ketentuan Kerangka Acuan bahasa-bahasa Eropa atau yang dikenal dengan nama Cadre européen commun de référence pour les langues (CECRL) yang disyahkan sejak tahun 2001 oleh Dewan Eropa (Conseil de l'Europe) dengan tingkatan kompetensi yaitu A1, A2, B1, B2 (DELF) dan C1, C2 (DALF).

Salah satu keterampilan berbahasa yang merupakan keterampilan terakhir dari empat keterampilan berbahasa adalah keterampilan menulis. Keterampilan menulis bukanlah merupakan keterampilan yang diperoleh secara alamiah melainkan perlu dipelajari atau dibudayakan pelatihannya, baik secara formal maupun lingkungan belajar lainnya. Hal ini senada dengan pernyataan Myles (2012) yang menjelaskan bahwa "The ability to write well is not a naturally acquired skill; it is usually learned or culturally transmitted as a set of practices in formal instructional settings or other environments". Selanjutnya ia menegaskan bahwa "Writing skills must be practiced and learned through experience". Hal ini mengandung arti bahwa keterampilan menulis harus terus dilatih dan dipelajari melalui pengalaman menulis.

Mengacu pada penjelasan di atas, jelas sudah bahwa kemahiran dalam menulis perlu dilakukan secara bertahap, berproses, dan berkesinambungan sehingga menjadikan suatu kebiasaan. Keterampilan menulis tentu saja tidak dilakukan secara langsung mempraktekkannya melainkan perlu juga seorang pembelajar mengetahui jenis teks yang akan ditulis agar selanjutnya mampu menghasilkan tulisan baik sesuai dengan jenis teks yang diinginkan.

$$
\text { Pemanfaatan teknologi mutlak }
$$

diperlukan dalam sebuah proses pembelajaran. Selain pengajar, pembelajar pun dituntut untuk dapat beradaptasi dengan kemajuan teknologi tersebut sehingga materi yang disampaikan di kelas dapat dikembangkan sebagai materi pengayaan berupa pencarian materi lain dari sumber daring (online).

Dalam pembelajaran bahasa asing dalam hal ini bahasa Perancis, penggunaan dokumen otentik (asli) dalam proses pembelajaran merupakan conditio sine quo non artinya sesuatu yang tidak dapat dihindari. Dengan kata lain, penggunaan dokumen otentik sudah menjadi keharusan agar para pembelajar lebih dihadapkan pada situasi nyata dari media yang digunakan oleh pengajarnya.

Begitu pula dalam pembelajaran keterampilan menulis teks bahasa Perancis, sebelum mampu menulis seorang pembelajar diharapkan terlebih dahulu mampu memahami bahan bacaan. Kegiatan membaca teks otentik baik dari sumber buku maupun dari sumber online sudah harus menjadi suatu kebiasaan bahkan tuntutan bagi para pembelajar bahasa Perancis tidak hanya sekedar membacanya melainkan pula untuk memahami dan menginterpretasikannya sejak awal mula perkuliahan untuk selanjutnya mampu menulis teks sejenis sebagai realisasi pemahamannya.

Salah satu jenis teks yang dapat digunakan sebagai bahan bacaan adalah teks surat kabar/koran dengan nama Textes Médiatiques. Menurut Cicurel dalam Benito (2009) yang dimaksud dengan textes médiatiques adalah "teks yang berasal dari surat kabar (la presse) seperti teks informatif (fait-divers), teks opini publik, iklan suatu produk, iklan layanan publik, berita aktual perihal suatu peristiwa olah raga, lingkungan, politik, social, kesehatan yang tujuannya adalah untuk memberikan informasi dan hiburan". 
Sekaitan dengan teks bahasa Perancis yang diperlukan untuk pembelajar tingkat lanjutan (A1/A2 DELF), teks informatif tersebut dapat diunduh dari berbagai laman dalam bahasa Perancis. Pada laman ini, tersedia ratusan berita actual yang disaijkan dalam bahasa Perancis sederhana dengan public pembaca anak-anak dan remaja. Teks yang disajikan dikemas dengan bahasa yang singkat, padat, mudah untuk dipahami dan dicerna oleh anak-anak dan remaja. Jenis teks tersebut dapat dikategorikan dalam teks untuk kompetensi membaca tingkat A1/A2 DELF. Berikut ini laman yang dapat digunakan dalam pembelajaran Bahasa Perancis.

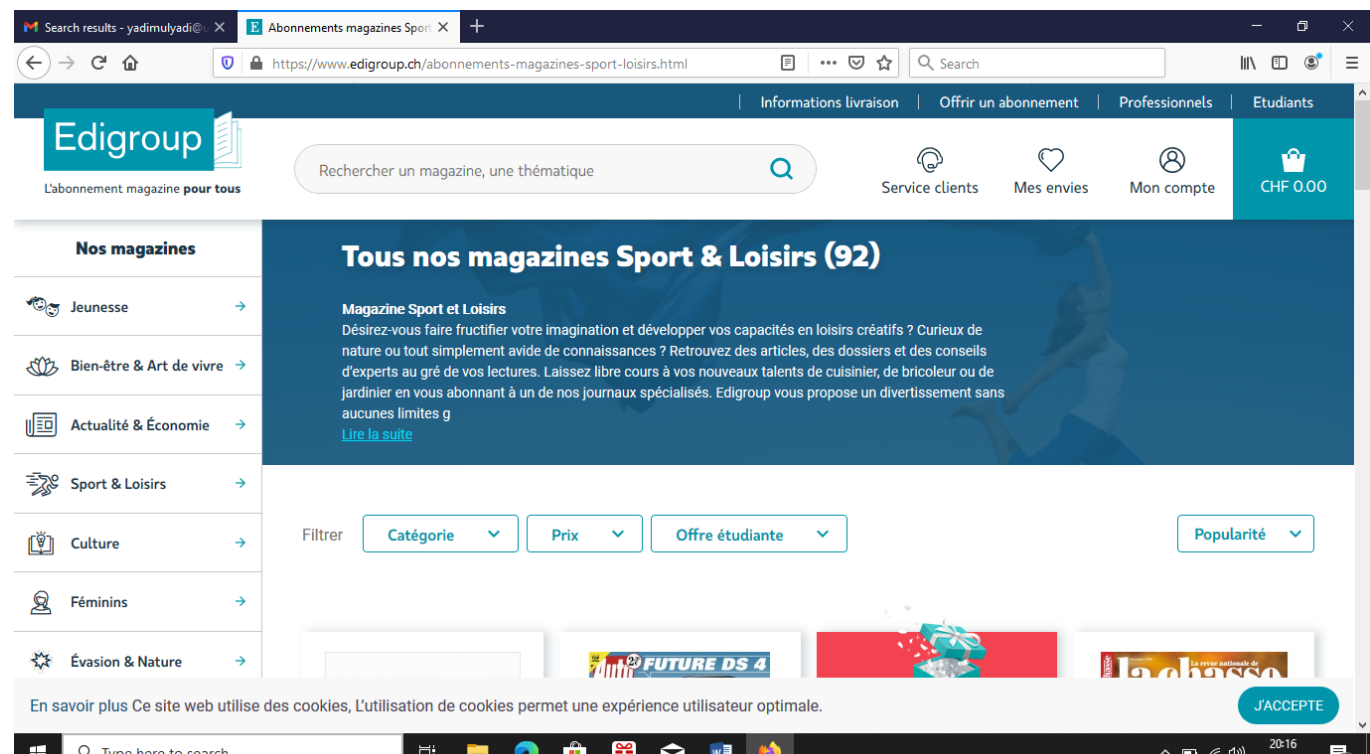

Gambar 1. Laman https://www.edigroup.ch.

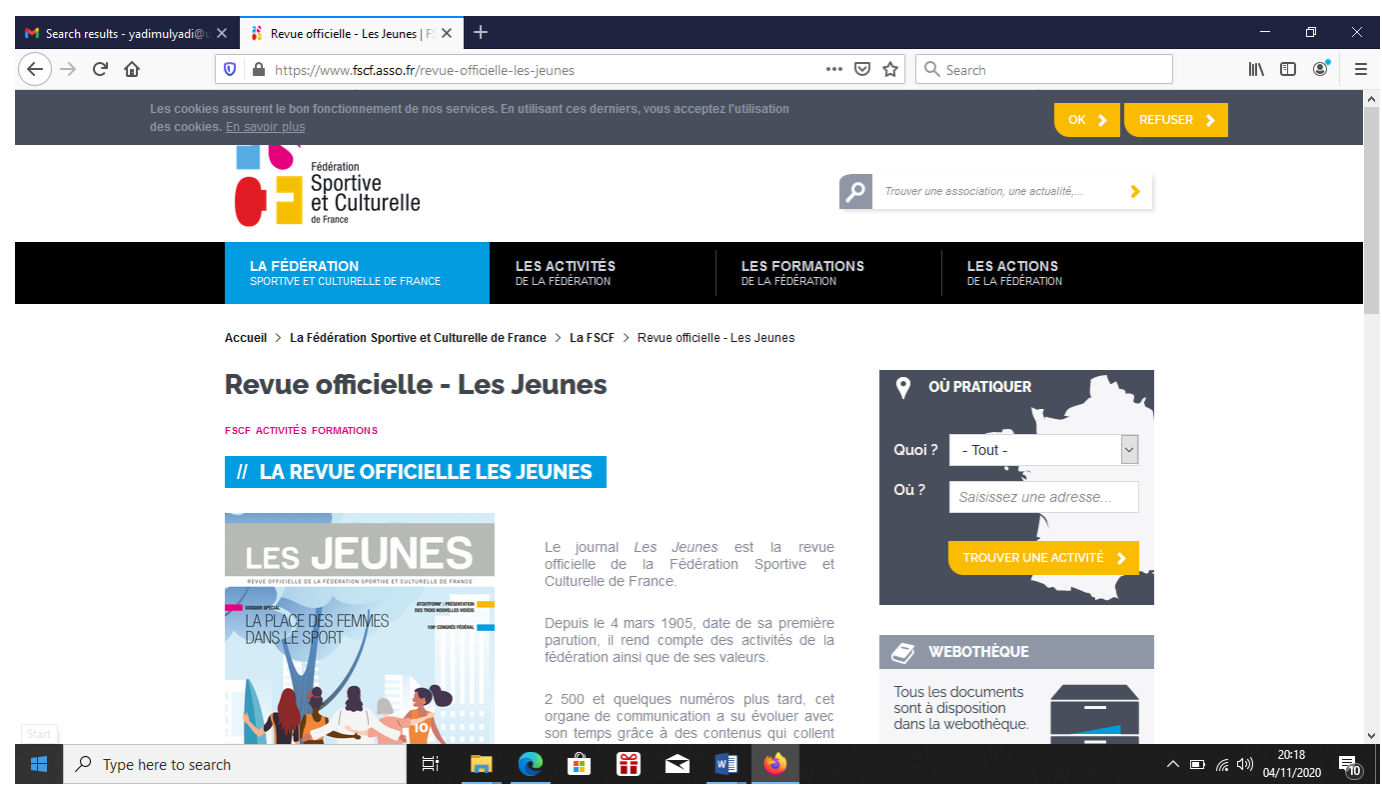

Gambar 2. Laman https://www.fscf.asso.fr

Menulis berita merupakan suatu upaya menyampaikan kabar atau sebuah informasi mengenai sesuatu hal atau kejadian dalam bentuk tertulis. Seorang 
penulis berita yang baik dapat menuliskan sebuah berita dengan lengkap dan komunikatif, sehingga pembaca berita dapat memahami segala sesuatu yang disampaikan dalam berita tanpa kesulitan dan tanpa adanya kesalahan tafsir.

Menurut Romli (2016, p.3) berita (news) merupakan sajian utama sebuah media massa di samping opini (views). Mencari bahan berita lalu menyusunnya merupakan tugas pokok wartawan dan bagian redaksi sebuah penerbitan pers (media massa).

Masih menurut Romli (2016), tidak ada rumusan tunggal mengenai perngertian berita. Bahkan menurut English dan Hach dalam Romli (2016), "News is difficult to define, because it involves many variabel factors". Namun terdapat sejumlah penulis memberikan defini berita. Berita adalah laporan atau pemberitahuan mengenai terjadinya sebuah peristiwa atau keadaan yang bersifat umum dan baru saja terjadi yang disampaikan oleh wartawan di media massa (Djuraid, 2012, p.12). Menulis berita merupakan suatu upaya untuk bercerita, menerangkan, atau menyampaikan informasi suatu peristiwa dalam bentuk tertulis. Dalam menulis teks berita, informasi yang ditulis merupakan fakta bukan opini. Teks berita disusun berdasarkan prinsip $5 \mathrm{~W}=1 \mathrm{H}$ (what, where, when, who, why, how). Di Indonesia, menulis teks berita mesti mengikuti kaidah P3SPS, yaitu Pedoman Perilaku Penyiaran dan Standar Program Penyiaran) yang telah dibuat oleh pemerintah.

Dalam menulis teks berita perlu dipahami beberapa unsurnya yaitu: actual, kedekatan, penting, luar biasa, tokoh, ekslusif, ketegangan, konflik, buman interest, seks, progresif, trend, dan humor (Djuraid, 2012, p. 13).

Untuk melihat macam berita, hal ini ditentukan oleh materi, kejadian, sifat peristiwa dan cara penulisannya (Djuraid, 2012, p. 72). Macam-macam berita di antaranya:

(a) Berita langsung (straight news), yaitu berita tentang peristiwa yang penting yang harus segera disampaikan kepada pembaca dan ditempatkan di halaman utama.

(b) Berita ringan (soft news), yaitu berita yang menampilkan sesuatu yang menarik, penting dan bersifat informatif.

(c) Berita kisah (feature), yaitu tulisan mengenai kejadian yang dapat mengunggah perasaan dan menambah pengetahuan pembaca melalui penjelasan yang rinci, lengkap, mendalam, dan tidak terpengaruh waktu. (Djuraid, 2012, p. 73).

Dalam meliput berita, terdapat tiga teknik peliputannya, yakni reportase, wawancara, dan riset kepustakaan atau studi literatur (Romli, 2016, p.7). Reportase adalah kegiatan jurnalistik berupa meliput langsung ke lapangan atau tempat kejadian perkara. Sedangkan wawancara merupakan proses peliputan berita dengan cara melakukan wawncara terhadap sumber berita atau narasumber. Wawancara bertujuan untuk menggali informasi, komentar, opini, fakta, atau data tentang suatu masalah. Adapun riset kepustakaan adalah teknik peliputan atau pengumpulan data dengan cara mengklipping koran, makalah-makalah atau artikel koran, menyimak brosur-brosur, membaca atau menggunakan fasilitas pencarian internet (Romli, 2016).

Selama proses pembelajaran keterampilan menulis pada Production Ecrite 1 dan 2 sebagai keterampilan menulis tingkat dasar yaitu pada level A1 dan A2 $D E L F$ seringkali peneliti temui kendala baik dari sisi peneliti sebagai pengajar maupun dari sisi mahasiswa/pembelajar. Di antara kendala yang kerap ditemui di antaranya adalah dalam pemahaman konsep penulisan bahasa Perancis sesuai kompetensi yang ditargetkan pada level tersebut, yaitu level A1 dan A2, dalam hal memahami strategi penulisan teks bahasa Perancis, analisis tulisan, orthographe, grammaire, type de textes, 
pengembangan tulisan dan evaluasi hasil tulisan yang telah dibuat.

Merujuk pada permasalahan di atas, dalam penelitian ini peneliti bermaksud untuk menerapkan teknik Peer review dalam proses pembelajaran menulis bahasa Perancis. Penelitian terkait penerapan Peer review telah banyak dilakukan di antaranya oleh Swain dan Tocalli-Beller (2002); DiGiovanni, dan Nagaswami (2001); Silver dan Coomber (2011), dan; Li dan Li (2018). Dari keseluruhan hasil penelitian tersebut dapat diperoleh temuan bahwa teknik Peer review dapat berkontribusi dalam memandirikan dan melatih keterampilan pembelajar dalam menulis dan mengoreksi hasil tulisan sesama temannya.

Peer review perlu diintegrasikan dalam pembelajaran keterampilan menulis bahasa Perancis dengan asumsi bahwa pada dasarnya kerjasama antara pengajar dan pembelajar begitu pula antarpembelajar bahasa mutlak diperlukan dalam kegiatan Peer review di antaranya dalam hal saling mengoreksi hasil tulisan yang telah disusun, saling memberikan masukan dan mendiskusikan hasil masukan tersebut secara bersama-sama.

Perlu dibedakan antara Peer review dengan Peer assessment terkait tujuan penilaian sumatif dan perangkingan. Hal ini senada dengan pendapat Somerville, 1993; Topping et al., 2000 dalam Pearce, Mulder dan Baik (2009) bahwa

"The peer-review process involves
collaborative learning in which students
assess one another's work (usually against
explicit criteria), and provide each other
with feedback. The process is formative
and has the aim of improving student
learning while it is happening, in order to
enhance understanding of the work
involved and hence improve the quality of
the final product. This is distinguished
from peer assessment for grading or
summative purposes".

Untuk memiliki keterampilan menulis, seorang pembelajar diperlukan untuk banyak membaca teks-teks yang disajikan baik di media cetak maupun elektronik. Saat ini, hampir seluruh surat kabar atau pun majalah menyediakan berita versi daring (online). Hal ini dilakukan pihak pengelola surat kabar atau majalah untuk mengimbangi zaman yang menuntut segalanya serba praktis sehingga beragam informasi banyak disajikan secara daring.

Sekaitan dengan permasalahan yang dikaji dalam penelitian ini, penelitian ini bertujuan untuk: (1) menilai penerapan teknik Peer review berbantuan artikel media daring untuk meningkatkan keterampilan menulis mahasiswa dalam pembelajaran Production Ecrite 2; dan (2) memperoleh data keterampilan menulis mahasiswa dalam menulis teks berita bahasa Perancis untuk level A2 DELF.

\section{Metode}

Pendekatan yang digunakan dalam penelitian ini adalah pendekatan kualitatif dan kuantitatif. Substansi permasalahan dalam penelitian ini lebih tepat didekati dengan menggunakan pendekatan kuantitatif, metode penelitian praeksperimen dan desain penelitian The One groupe pre-test and post-test design. Penelitian ini dilaksanakan di salah satu universitas di kota Bandung, Jawa Barat. Subjek penelitian ini adalah mahasiswa pembelajar bahasa Perancis sebagai bahasa asing dengan mengambil sampel karakteristik keterampilan menulisnya. Instrumen pengumpul data yang digunakan dalam penelitian ini berupa tes, dalam hal ini hasil tes keterampilan menulis teks informatif mahasiswa yang diperoleh dari hasil prates (tes awal), dan hasil pascates (tes akhir).

\section{Hasil dan Pembahasan}

Pelaksanaan penelitian praeksperimen ini melibatkan 1 kelompok (1 kelas) yaitu kelompok eksperimen tanpa pembanding atau tanpa kelompok kontrol. Kelompok eksperimen diberikan perlakuan dengan menggunakan metode Peer Review berjumlah 27 orang partisipan. Adapun materi yang diberikan yaitu menulis teks informatif 
dalam bahasa Perancis dengan bantuan artikel media daring sebagai media bantunya. Pada penelitian ini peneliti bertindak sebagai observer. Kegiatan yang dilakukan pada tahapan perencanaan penelitian meliputi penyiapan Rencana Pembelajaran Semester (RPS), penyusunan pedoman penilaian, penyiapan materi yang sesuai dengan kompetensi yang akan diajarkan dan pembuatan media pembelajaran berupa tayangan materi. Aspek penilaian menulis teks berita dalam penelitian ini meliputi: (1) Isi gagasan yang dikembangkan (Respect de la consigne); (2) Organisasi pengembangan isi (Capacité à présenter des faits et sa pensée); (3) Tata bahasa (Morphosyntaxe - orthographe lexicale); (4) gaya penulisan (Cobérence et cohesion), dan; (5) Pengembangan kalimat dan ejaan (Degré d'élaboration des phrases et la ponctuation).

Dari kelima aspek penilaian di atas, aspek tata bahasa (Morphosyntaxe orthographe lexicale) (kriteria penilaian 3) merupakan kendala yang paling banyak ditemukan dalam penelitian ini. Pada hasil tes baik pada tes awal maupun pada tes akhir terdapat banyak kesalahan tata bahasa. Selain itu, kendala lainnya yaitu ketidakmampuan dalam hal aturan dan penyajian penulisan teks informatif (kriteria penilaian 1).

Sekaitan dengan perancangan model pembelajaran menulis teks informatif dalam bahasa Perancis berbasis Peer review, berikut ini disajikan tahapan proses pembelajarannya yang diadaptasi dari Gratadour (2008) dalam Mulyadi (2015).

\section{Phase 1 (5 min)}

Découverte de l'bistoire. L'exemple du texte journalistique est lu/présente par le maître.

\section{Phase 2 (5 min)}

Contraintes d'écriture. Sur la feuille de brouillon, les élèves écrivent la consigne afin de bien l'intégrer.

\section{Phase 3 (5 min)}

Conceptualisation. Cette phase est indispensable et doit donner lieu à un « cérémonial»: silence absolu, aucune activité parasite (trousse...), attitude concentrée (fermer les yeux...) J'invente l'idée ou l'bistoire dans ma tête. Elle doit «tenir toute dans ma tête, du début à la fin ».

\section{Phase 4 (10 min)}

Les élèves écrivent au crayon à papier sur la fenille sur laquelle ils ont écrit la consigne. C'est cependant une fenille de bromillon sur laquelle on va pouvoir retravailler son texte.

\section{Phase 5 (15 min)}

Première validation par le maître. Dès que le travail est terminé, il est présenté au maître. Le maître lit le texte présenté et questionne individuellement chaque élève sur les points définis par les consignes. Le maitre donne des orientations de travail, rectifie le texte si nécessaire (cas d'imperfections que l'élève n'est pas encore en mesure d'améliorer seul).

\section{Phase 6 (15 min)}

Travail sur le texte. Il ne s'agit pas d'une réécriture mais d'un retour sur l'écrit initial pour gommer, barrer, réécrive un mot, une phrase, un paragraphe, afin de remédier à des incobérences, d'éliminer des répétitions (en tenant compte des notions acquises au fil de l'année).

\section{Phase 7 (5 min)}

Mise au propre par l'élève sur une nouvelle fenille: la consigne est à nouveau notée.

\section{Phase 8 (15 min)}

Deuxième validation individuelle par le maître des modifications apportées par l'elève. Cette validation n'est pas systématique. Il faut accepter que l'elève mette au propre un texte "imparfait" mais néanmoins acceptable par rapport aux consignes d'écriture. Ce travail permet au maître d'identifier les difficultés récurrentes, les élèves en difficultés et de prévoir les séances de renforcement (pour tous) ou de remédiation (pour certains).

Le maître corrige, en écrivant si nécessaire sur la feuille de l'élève. Ce texte peut être considéré comme la trace finale ou l'élève peut recopier de nouvean son texte. Le texte est rangé dans un outil spécifique réservé à la rédaction avec ou sans les différentes étapes de l'écriture. 
Phase 9 (10 min)

Le maitre demande aux élèves de corriger le travail de leurs voisins. Les élèves corrigent le travail des voisins.

\section{Phase 10 (15 min)}

Le maitre ouvre la session de discussion sur le texte des élèves.
Kegiatan awal pembelajaran menggunakan teknik Peer review dimulai dengan menyiapkan pembelajaran sebagaimana biasanya. Pengajar/peneliti melakukan apersepsi dan tes awal dengan cara menyajikan sebuah teks berita di depan kelas. Berikut ini contoh teks berita informatif dari laman yang digunakan dalam pembelajaran.

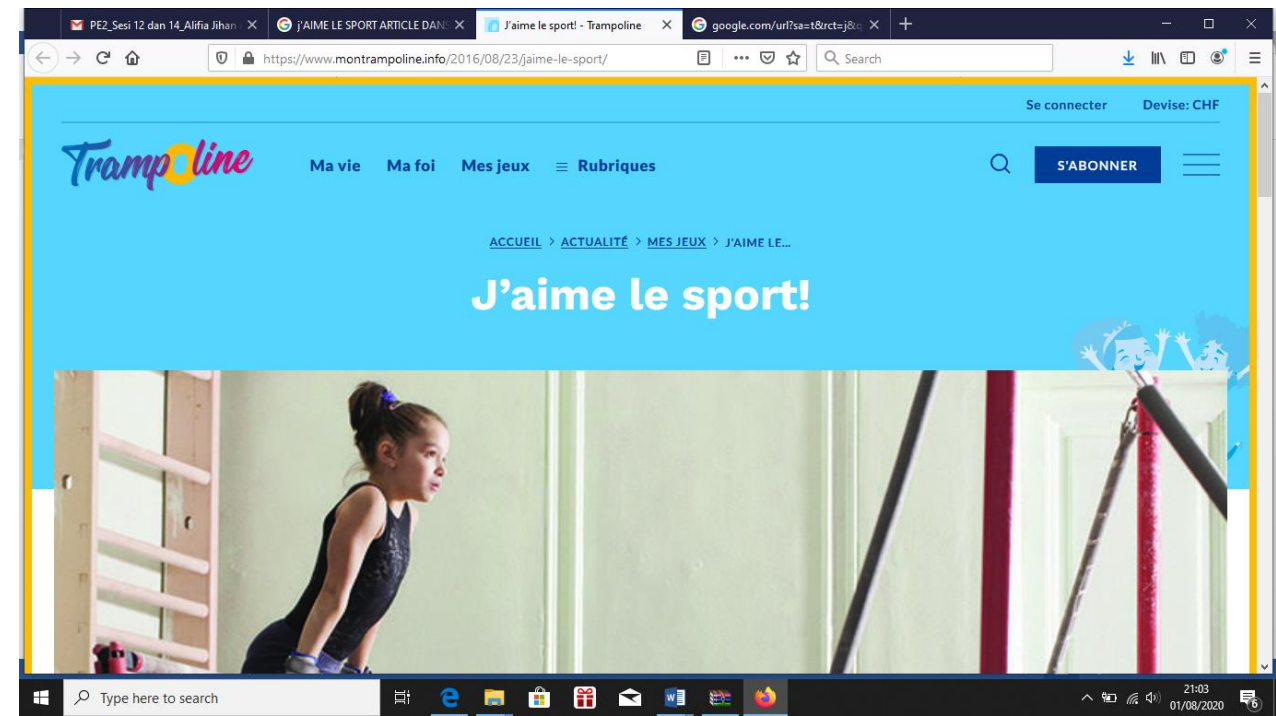

Gambar 3. Laman utama Trampoline pada http://trampoline.fr

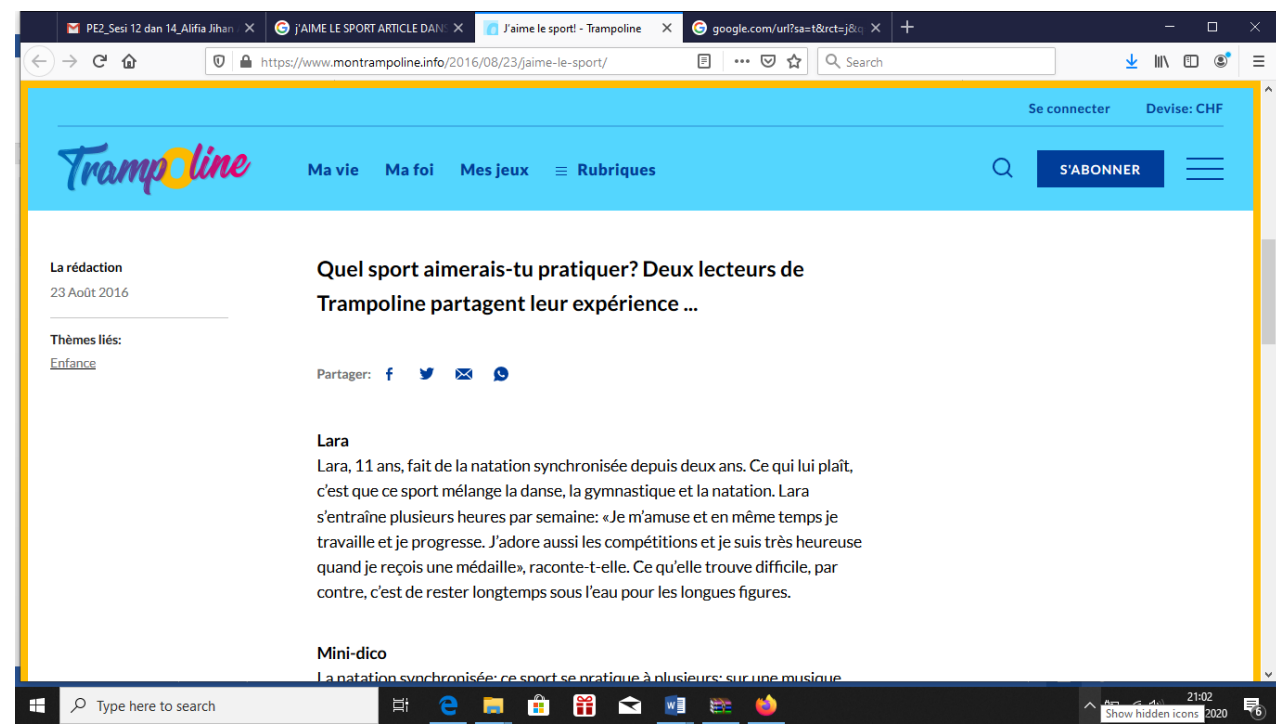

Gambar 4. Berita olahraga pada laman Trampoline http://trampoline.fr 


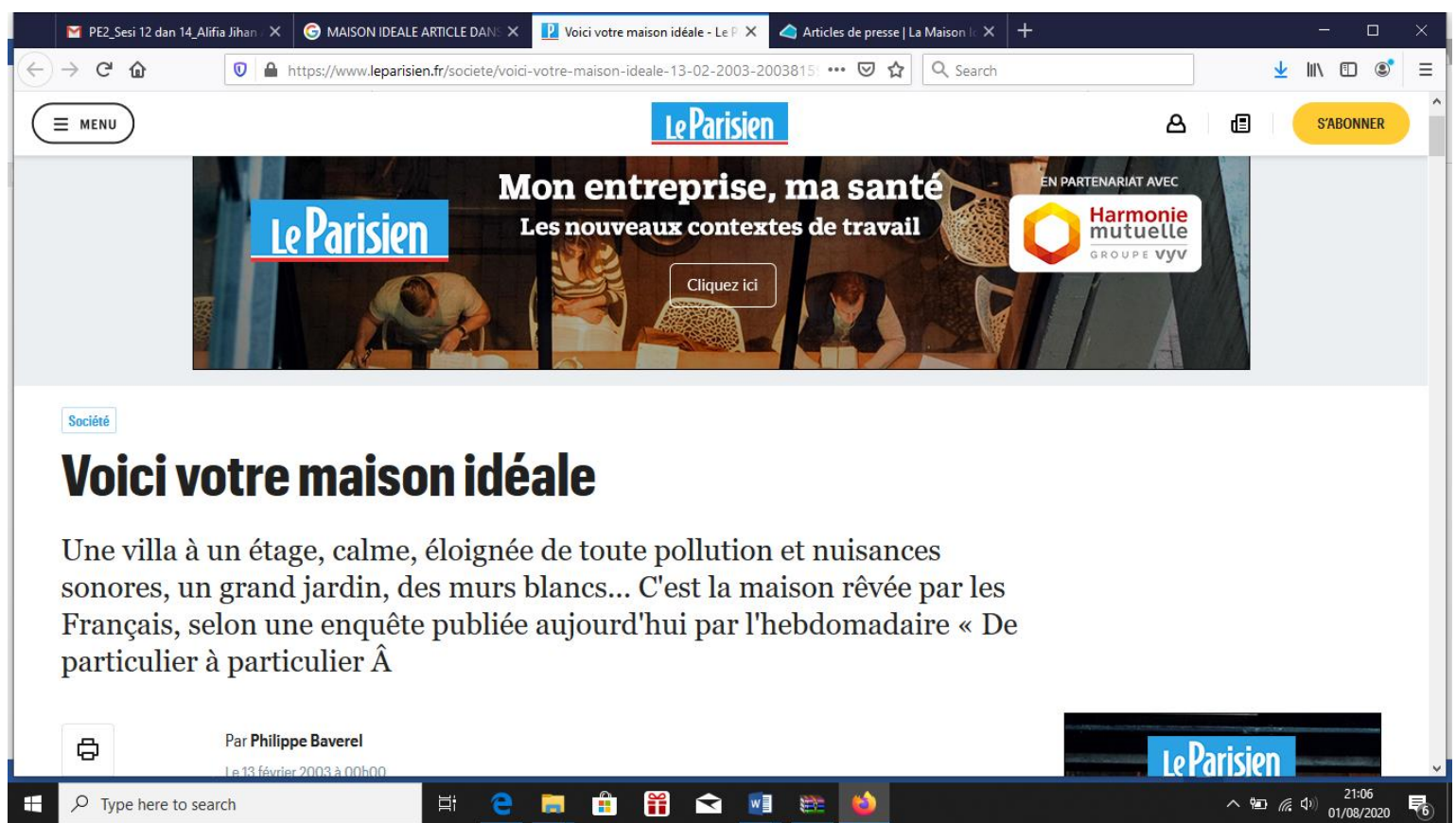

Gambar 5. Laman Utama Le Parisien pada http://leparisien.fr

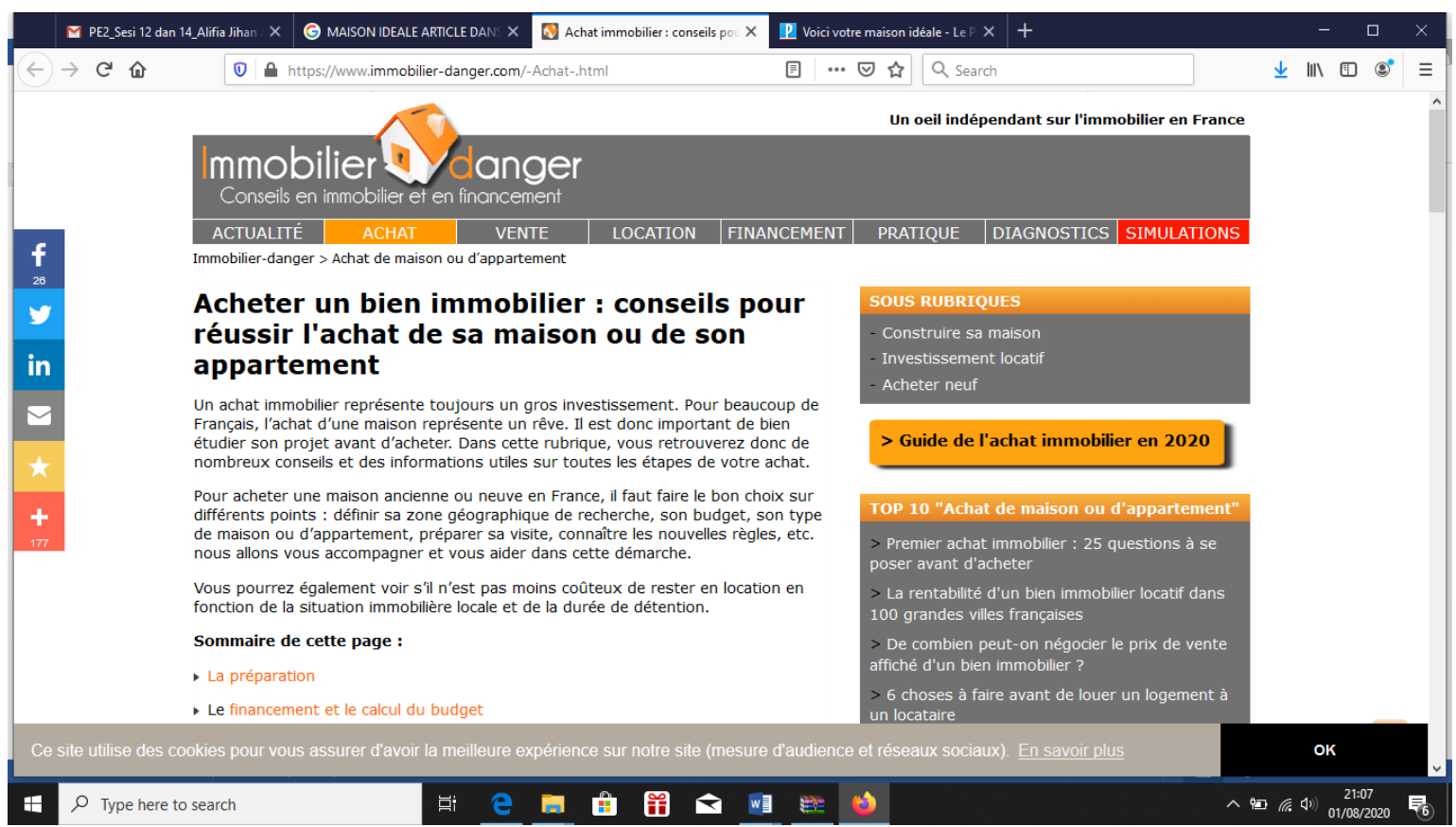

Gambar 6. Berita iklan pada laman Le Parisien pada http://leparisien.fr

Kemudian pengajar memberikan gambaran tentang teks informatif yang disajikan. Kemudian mahasiswa dibagi ke dalam beberapa kelompok. Mahasiswa lalu diberi salinan contoh teks informatif. Pengajar/ peneliti kemudian menjelaskan tugas yang harus dikerjakan oleh mahasiswa yaitu tugas mempelajari teks informatif/berita.

Setelah mahasiswa selesai mendiskusikan tugas bersama kelompoknya, kemudian pengajar 
menunjuk salah satu mahasiswa dalam masing-masing kelompok untuk menjelaskan isi dari teks berita yang telah dibaca dan unsur apa saja yang membentuk teks informatif. Setelah itu, pengajar meminta mahasiswa untuk menulis teks informatif dengan bantuan gambar yang ditayangkan dalam video dan slides power point yang telah ditayangkan oleh pengajar. Setelah hasil tulisan selesai, antarmahasiswa dalam kelompok saling bertukar hasil tulisan dan masing-masing mengoreksi hasil tulisan teman dalam kelompoknya. Untuk penilaian hasil tulisan, mahasiswa menggunakan kriteria penilaian yang telah diberikan oleh pengajar. Setelah saling mengoreksi hasil tulisan sesama teman, lalu pengajar memandu seluruh kelompok untuk mengoreksi tulisan secara bersamasama. Hasil tulisan mahasiswa selanjutnya dikoreksi oleh pengajar. Hasil koreksi pengajar disampaikan secara individual kepada seluruh mahasiswa. Di akhir pembelajaran, pengajar menyimpulkan hasil dari penulisan teks berita pada sesi tersebut.

Pada tes awal jumlah mahasiswa yang mendapat nilai baik sebanyak 3 mahasiswa, yang mendapat nilai cukup sebanyak 22 mahasiswa, yang mendapat nilai kurang sebanyak 2 mahasiswa, yang mendapat nilai sangat baik dan kurang sekali tidak ada. Nilai tertinggi pada tes awal ini adalah 78 dan nilai terendah adalah 55 .

Setelah diberikan perlakuan pembelajaran dengan teknik yang telah dipelajari, selanjutnya diberikan tes akhir. Adapun hasil tes akhir yang diadakan setelah pembelajaran, jumlah mahasiswa yang mendapat nilai sangat baik sebanyak 6 mahasiswa, yang mendapat nilai baik sebanyak 16 mahasiswa, yang mendapat nilai cukup sebanyak 5 mahasiswa, yang mendapat nilai kurang dan kurang sekali tidak ada. Nilai tertinggi pada tes ini adalah 90 dan terendah adalah 73. Dengan perhitungan statistika diperoleh hasil ratarata nilai ( ) tes awal adalah $=67,46$. Standar deviasi $(\mathrm{Sd})=5,38$ dan untuk tes akhir ratarata nilai ( ) adalah 79,55, standar deviasi $(\mathrm{Sd})=5,62$. Distribusi frekuensi nilai tes awal dan tes akhir kelompok ekperimen dapat dilihat pada tabel 1 dan tabel 2, serta histogramnya adalah gambar 2 dan gambar 3.

Tabel 1. Distribusi Frekuensi Nilai Tes Awal

\begin{tabular}{|l|l|l|l|}
\hline No & Interval Nilai Tes & Frekuensi Absolut & Frekuensi Reltif (\%) \\
\hline 1 & $78-75$ & 3 & 11,11 \\
\hline 2 & $74-71$ & 4 & 14,81 \\
\hline 3 & $70-67$ & 9 & 33,33 \\
\hline 4 & $66-63$ & 7 & 25,93 \\
\hline 5 & $62-59$ & 2 & 7,41 \\
\hline 6 & $58-55$ & 2 & 7,41 \\
\hline Jumlah & 27 & 100 \\
\hline \multicolumn{2}{|l|}{ Rata-rata $(\bar{X})$} & 67,46 & \\
\hline \multicolumn{2}{|l}{ Standar Deviasi $(\mathrm{Sd})$} & 5,38 & \\
\hline
\end{tabular}




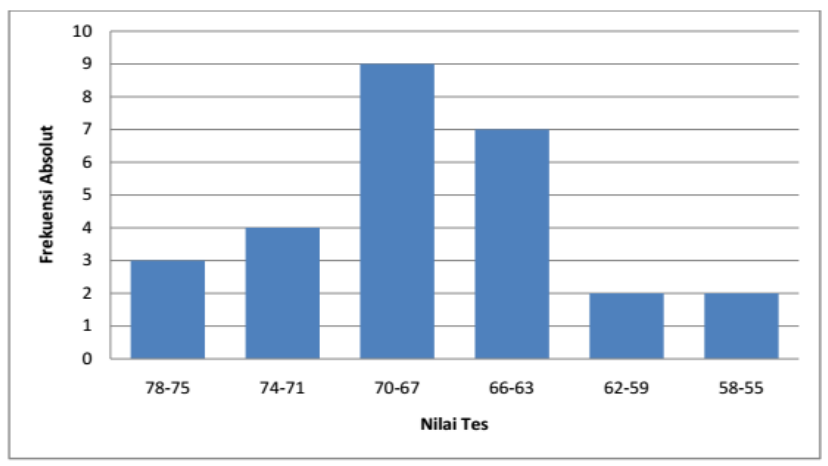

Gambar 7. Grafik Nilai Tes Awal

Setelah dilaksanakan perlakuan pembelajaran dengan menggunakan teknik Peer review berbantuan artikel media daring, maka diperoleh data tes akhir sebagai berikut.

Tabel 2. Distribusi Frekuensi Nilai Tes Akhir

\begin{tabular}{|l|l|l|l|}
\hline No & Interval Nilai Tes & Frekuensi Absolut & Frekuensi Reltif (\%) \\
\hline 1 & $90-88$ & 4 & 14,81 \\
\hline 2 & $87-85$ & 2 & 7,41 \\
\hline 3 & $84-82$ & 4 & 14,81 \\
\hline 4 & $81-79$ & 3 & 11,11 \\
\hline 5 & $78-76$ & 4 & 14,82 \\
\hline 6 & $75-73$ & 10 & 37,04 \\
\hline Jumlah & 27 & 100 \\
\hline \multicolumn{2}{|l|}{ Rata-rata $(\bar{X})$} & 79,55 & \\
\hline \multicolumn{2}{|l}{ Standar Deviasi (Sd) } & 5,62 & \\
\hline
\end{tabular}

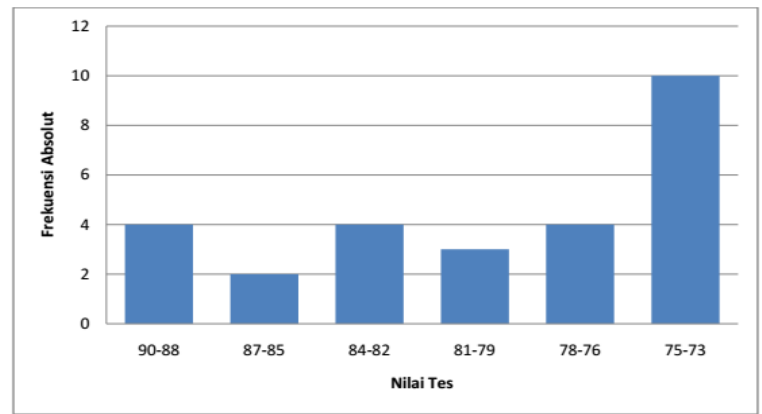

Gambar 8. Grafik Nilai Tes Akhir

Tabel 3. Perhitungan nilai perbedaan tes awal dan tes akhir

\begin{tabular}{|l|l|l|l|l|l|}
\hline Tes & $\mathrm{N}$ & Mean & Md & $\mathrm{T}_{\text {hitung }}$ & $\mathrm{T}_{\text {tabel }}$ \\
\cline { 1 - 3 } Tes Awal & 27 & 67,46 & \multirow{2}{*}{11,96} & 16,16 & 2,056 \\
\cline { 1 - 3 } Tes Akhir & 27 & 79,55 & & & \\
\hline
\end{tabular}

Dari uji $\mathrm{t}$ yang dilakukan maka diperoleh nilat t-hitung sebesar 16,16 yang ternyata nilai tersebut lebih besar dari pada nilai t-tabel 5\% yaitu 2,056. Dengan demikian berarti bahwa terdapat perbedaan yang signifikan antara tes awal dan tes akhir pada kelompok eksperimen. 
Berdasarkan hasil pengujian dari tes awal dan tes akhir di atas, maka dapat diambil kesimpulan bahwa terjadi peningkatan kemampuan awal dan kemampuan akhir mahasiswa setelah pemberian perlakuan pembelajaran dengan teknik Peer review.

Dari data-data penelitian yang telah dianalisis, diperoleh temuan yaitu rata-rata skor tes awal kelas eksperimen $=67,46$, ini menunjukan kemampuan awal mahasiswa tentang materi yang diujikan masih sangat rendah karena umumnya mahasiswa belum mempelajarinya. Setelah diberikan perlakuan berupa pembelajaran dengan teknik Peer review, diadakan tes akhir dengan hasil rata-rata skor adalah 79,55. Terjadinya peningkatan hasil tes ini, karena mahasiswa membuat teks informatif berdasarkan pengetahuan yang telah dipelajarinya dari perlakuan pembelajaran yang telah diberikan.

Merujuk pada hasil penelitian di atas, diperoleh informasi bahwa teknik pembelajaran yang diteliti telah terbukti efektif dan mampu meningkatkan keterampilan menulis teks informatif bahasa Perancis untuk tingkat A2. Dengan adanya hasil temuan di atas, dapat diperoleh informasi bahawa para mahasiswa mengalami sejumlah kendala di antaranya dalam: (1) Kurangnya perbendaharaan kata (vocabulaire) terkait tema-tema yang diulas dalam teks informatif yang dikaji. Hal ini dikarenakan mereka belum terbiasa dalam membaca dan memahami teks informatif baik daring maupun cetak dalam bahasa Perancis; (2) Kurangnya pemahaman terkait istilah-istilah jurnalistik (terme journalistique) sehingga menyulitkan mereka dalam mengemas teks berbahasa Perancis; (3) Kurangnya pemahaman gramatika yang mesti dikuasai pada level-level tertentu, khususnya untuk level $A 2$ yang tentu saja memerlukan banyak kajian gramatika dikarenakan pada level ini tuntutannya lebih tinggi dibandingkan A1.

Dengan hasil yang telah diperoleh ini, dapat dipahami bahwa dalam proses penerapan teknik Peer review pada pembelajaran menulis teks informatif terdapat tiga jenis masukan (feedback) yang diberikan pada pembelajar dalam penelitian ini, yaitu: peer feedback, teacher feedback, dan group feedback. Hal ini sejalan dengan hasil penelitian Andreani (2009) bahwa "all writers have difficulty seeing/noticing what they have written with objectives eyes". Selebihnya, hasil penelitian ini berkontribusi dalam penerapan teknik peer review dalam menulis teks informatif bahasa Perancis, dan mampu membantu mahasiswa dalam memahami dan meningkatkan kemampuan dalam menulis teks informatif bahasa Perancis sesuai kaidah jurnalistik.

\section{Simpulan}

Mengacu pada hasil yang telah dicapai, peneliti dapat mengungkapkan bahwa: (1) teknik Peer review telah terbukti efektif untuk meningkatkan keterampilan mahasiswa dalam menulis teks informatif dalam bahasa Perancis untuk tingkat A2 DELF, dan (2) kendala-kendala yang dtemui mahasiswa di antaranya adalah: (a) kurangnya perbendaharaan kata (vocabulaire) terkait tema-tema yang diulas dalam teks jurnalistik yang dikaji. Hal ini dikarenakan mereka belum terbiasa dalam membaca dan memahami teks jurnalistik baik daring maupun cetak; (b) Kurangnya pemahaman terkait istilah-istilah jurnalistik (terme journalistique) sehingga menyulistkan mereka dalam mengemas teks bahasa Perancis; (c) Kurangnya pemahaman gramatika yang mesti dikuasai pada level-level tertentu, terutama untuk level $A 2$ yang tentu saja memerlukan banyak kajian gramatika dikarenakan pada level ini tuntutannya lebih tinggi.

\section{Daftar Rujukan}

Andreani, W. (2009). "A comparison between peer and teacher feedback on learners'language accuracy: a case study". Celt: Culture, English Language, Teaching and Literature, 9(1), 2009, pp.42-59. 
Benito, J.A. (2009). La lecture et le document authentique en classe de français langue étrangère. International Journal Synergies, Mexique, 1(1), 607617.

DiGiovanni, E., \& Nagaswami, G. (2001). Online peer review: An alternative to face-to-face?. ELT journal, 55(3), 263272.

Djuraid, H.N. (2012). Panduan menulis berita. $4^{\text {th }}$ edition Malang: UMM Press.

Graham, S. J. (2004). Giving up on modern foreign languages? Students' perceptions of learning French. The Modern Language Journal, 88(2), 171191.

Li, J., \& Li, M. (2018). Turnitin and peer review in ESL academic writing classrooms. Language Learning \& Technology, 22(1), 27-41.

Mulyadi, Y. (2015). Aplikasi pendekatan aksional dan media textes médiatiques pada laman www.jde.fr dalam meningkatkan keterampilan menulis teks jenis fait divers. Jurnal Barista: Jurnal Kajian Bahasa dan Pariwisata, 2(1), 45-65. Diakses dari :https:/ / ejournal.stp-

bandung.ac.id/index.php/v01/articl e/view/32

Myles, J. (2012). Second Language Writing and Research: The Writing Process and Error Analysis in Student Texts: Diakses dari: http://www.cc.kyoto-

su.ac.jp/information/teslej/ej22/a1.2012.html

Pearce, J., Mulder, R., \& Baik, C. (2009). Involving students in peer review. Australia: Centre for the Study of Higher Education The University of Melbourne. Diakses dari: http:/ /www.cshe.unimelb.edu.au

Silver, R., \& Coomber, M. (2011). How anonymity affects feedback in the peer review process. KOTESOL Proceedings 2010, 299.

Swain, M., Brooks, L., \& Tocalli-Beller, A. (2002). Peer-Peer dialogue as a means of second language. Annual Review of Applied Linguistics, 22, 171-185.
Rakhmat, S., Mulyadi, Y., \& Sopiawati, I. (2007). Pendekatan Semiotika Sebagai Pendekatan Alternatif Dalam Pembelajaran Analisis Teks Bahasa Prancis. Jurnal Fokus 1(1), 44-53.

Williams, M., Burden, R., Poulet, G., \& Maun, I. (2004). Learners' perceptions of their successes and failures in foreign language learning. Language Journal, 30(1), 19-29. 